\title{
Larval growth and biochemical composition of the protected Mediterranean spider crab Maja squinado (Brachyura, Majidae)
}

\author{
G. Rotllant ${ }^{1, *}$, G. Guerao ${ }^{2}$, N. Gras ${ }^{2}$, A. Estévez ${ }^{2}$ \\ ${ }^{1}$ Institut de Ciències del Mar, Consejo Superior de Investigaciones Científicas, Passeig Marítim de la Barceloneta, 37-49, \\ 08003 Barcelona, Spain \\ ${ }^{2}$ IRTA, Unitat Operativa de Cultius Experimentals, Ctra. Poble Nou, Km 5.5, 43540 Sant Carles de la Ràpita, Tarragona, Spain
}

\begin{abstract}
The spider crab Maja squinado is restricted to the Mediterranean Sea, and as captures of this species became very rare in the last decades, it is a protected species. To improve spider crab production in experimental or commercial hatcheries and allow the future success of restocking programmes, knowledge of larval growth and biochemical characteristics is mandatory. In the present study, larvae from 4 different batches were studied. Larvae were examined to determine the larval instar and moulting stages. In each moulting stage for all larval instars, carapace length, dry weight, ash and proximal composition (protein, carbohydrates and lipids) were measured. Metamorphosis began at $14 \mathrm{~d}$ posthatching (dph), with metamorphosis to the first juvenile crabs completed in about $90 \%$ of the specimens at $17 \mathrm{dph}$. Survival dropped from $59.25 \pm 19.53 \%$ to $33.49 \pm 19.53 \%$ between the zoea II and megalopa stages, and only $7.74 \pm 1.94 \%$ of newly hatched larvae (NHL) reached the first juvenile crab stage. NHL weighed $120.40 \pm 18.95 \mu \mathrm{g}$, increasing their dry weight and ash content 6 -fold after metamorphosis. Dry weight also increased through the moulting cycle in each larval instar, while ash content was higher in early premoult stages. Proximal composition increased between 8- and 6-fold from NHL to megalopa in the premoult stage and then decreased 2-fold during metamorphosis. Lipid and protein content varied among moulting stages from the postmoult to the premoult stages, with more significant alterations seen during the megalopa instar stage.
\end{abstract}

KEY WORDS: Decapoda $\cdot$ Majoidea $\cdot$ Larval instars $\cdot$ Moult stages $\cdot$ Size $\cdot$ Biomass $\cdot$ Protein $\cdot$ Lipids Resale or republication not permitted without written consent of the publisher

\section{INTRODUCTION}

The sustainability of exploitable marine resources and the conservation of biodiversity in the Mediterranean Sea are 2 of the major topics of on-going and future research in European waters. The Mediterranean is globally considered an oligotrophic sea, and represents $0.82 \%$ of the world's oceans. However, despite its small volume, it presents considerable heterogeneity and includes 4 to $18 \%$ of the world's marine diversity, depending on the phylum considered. Benthic communities are among the most diverse in the Mediterranean Sea and are highly sensitive to perturbations (natural or anthropogenic).
Currently, the biodiversity of the Mediterranean is undergoing rapid alteration under the combined pressure of overfishing, invasive species and climatic changes (Durrieu de Madron et al. 2011 and references therein).

In the last decades of the twentieth century, the spider crab Maja squinado (Herbst 1788) became a target species in fisheries in the Mediterranean and was quickly overfished (Abad 2003). Along the Spanish Mediterranean coast, as well as the Catalan coast and the Balearic Islands, only a few specimens have been captured since late 1980 (Rotllant et al. 2010a). Because of its high ecological value and the diminished size of its population, M. squinado is among the 
species included in the Action Plan for the Mediterranean (UNEP 1996). The Bern Convention on the conservation of wildlife and natural habitats, opened for signature on 19 September 1979 and ratified by the EU in Strasbourg in 1997, established $M$. squinado as a species of protected wildlife in the Mediterranean (Anonymous 1999) and its exploitation in Spain is regulated by general courts (Anonymous 1998).

Re-stocking is one of the options for allowing depleted stocks to recover. The restocking programmes include plans for evaluating the stock after releasing cultured individuals of the target species, and when recovery is sufficient, limited fisheries can be established in the area (Bell et al. 2008, Lorenzen et al. 2012). Overall, the focus has been on developing methods for mass-producing environmentally fit juveniles and releasing them in ways in which they survive without affecting the ecosystem or genetic diversity of wild stocks. Trial release programmes for enhancing or improving stocks of several severely depleted crab species have been implemented in Asia and North America, using aquaculture techniques as a tool for producing juveniles. Examples are the swimming crab Portunus trituberculatus (Okamoto 2004), the blue crab Callinectes sapidus (Zohar et al. 2008), the mud crabs Scylla paramamosain (Ut et al. 2007, Liu et al. 2011), Scylla olivacea and Scylla serrata (Lebata et al. 2009), and the red king crab Paralithodes camtschaticus (Daly et al. 2009, 2012, 2013, Swingle et al. 2013).

Maja squinado is a spider crab species restricted to the Mediterranean Sea (Neumann 1998, d'Udekem d'Acoz 1999, Sotelo et al. 2008, Sotelo et al. 2009, Guerao et al. 2011). A re-stocking programme for $M$. squinado in the western Mediterranean Sea (in particular, the Catalan coast and the Balearic Islands) was carried out during 2006-2010. The larval development of $M$. squinado comprises 2 zoeal instars and a megalopa (Guerao et al. 2008). The first studies on embryonic, larval and juvenile culture of $M$. squinado in captivity have recently been carried out. Guerao \& Rotllant (2010) cultured individually juveniles from megalopa to crab 8 in $154 \mathrm{~d}$, showing that sexual differentiation occurred at the crab 4 instar, the moult increment was $21-35 \%$ and the survival rate was $5.8 \%$. Newly moulted juveniles (C1 instar) were stocked and maintained together in a $1 \mathrm{~m}^{3}$ round fiberglass tank for mass culture, where the moult increment was 38\% (Pastor et al. 2011). Durán et al. (2012) reported an embryonic development duration of $32 \mathrm{~d}$ and a larval development duration of $17 \mathrm{~d}$ at around $19^{\circ} \mathrm{C}$. Individual changes in biomass during moult cycles can be used to quantitatively describe and compare the basic patterns of development and growth in decapod larvae (Anger 2001, Rotllant et al. 2012). For the spider crab M. brachydactyla, the biochemical composition during larval development has been determined and both biomass and biochemical composition are considered useful indicators of this species' larval condition (Andrés et al. 2010, Rotllant et al. 2010b).

The aim of the present study is to describe the morphometry, biomass and proximal composition of the larval instars of Maja squinado throughout the moult cycle in order to provide tools for improving $M$. squinado culture, to allow success in their production for re-stocking programmes. The results are compared with those obtained from the related species M. brachydactyla.

\section{MATERIALS AND METHODS}

\section{Maintenance of broodstock and larval rearing}

Adult Maja squinado (8 males and 24 females, $140 \pm 17 \mathrm{~mm}$ [mean $\pm \mathrm{SD}$ ] carapace length) were captured by local fishermen in the western Mediterranean in April 2009 (Catalonian coast, $\mathrm{n}=3$ males and 8 females) and April 2010 (NW Corsica, $\mathrm{n}=5$ males and 16 females), and transported in cooled, humid containers (ca. $8^{\circ} \mathrm{C}$; animals were wrapped with tissues soaked in seawater) to Institut de Recerca i Tecnologia Agroalimentàries (Sant Carles de la Ràpita, Tarragona, Spain) by road (the trip lasted from 2 to $16 \mathrm{~h}$ depending on the fishing location). Ovigerous females were kept in $1500 \mathrm{l}$ broodstock tanks connected to a recirculation unit (IRTAMar, Ingesom) maintaining a constant salinity of $34 \mathrm{ppt}$ and a temperature of $18 \pm 1^{\circ} \mathrm{C}$. Each broodstock tank contained females collected from the same area; we did not mix specimens from Catalonia and Corsica. Larvae were released from 4 different females ( 2 from Catalonia and 2 from Corsica) during late spring and summer. Immediately after each hatching event, actively swimming newly hatched first zoea larvae (NHL) were collected from the broodstock tanks and transferred to 34 PVC cylinders (35 l) with $150 \mu$ m mesh bottoms. Every day, 2 cylinders were sampled. Each PVC cylinder contained $2100 \mathrm{NHL}$ at the beginning of the experiment. The PVC cylinders were kept in 3 holding tanks of $1500 \mathrm{l}$ connected to a recirculation unit that maintained seawater at a salinity of $36 \mathrm{ppt}$ and a constant temperature of $18 \pm 0.5^{\circ} \mathrm{C}$, under a $14 \mathrm{~h}$ light:10 h dark photoperiod. Larvae were fed 
with enriched Artemia metanauplii at a feeding ratio of 60 metanauplii larvae ${ }^{-1} \mathrm{~d}^{-1}$. Artemia metanauplii were enriched with EasySelco (INVE, Belgium) at $0.6 \mathrm{~g} \mathrm{l}^{-1}$ in seawater for $24 \mathrm{~h}$. For further details on broodstock and larval culture conditions, see Andrés et al. $(2007,2008)$.

\section{Larval sampling and biometric and biomass measurements}

Larvae from 4 different broods were reared following the same sampling procedure for each brood. Every day, 2 PVC cylinders were emptied and all the larvae were collected, counted and sampled for survival, moulting and developmental stage, after which samples were kept for further analyses. In order to avoid confusion, we will hereafter use the terminology proposed by Anger (2001) and adopted by (Guerao et al. 2010): zoeae and megalopa will be referred to as larval instars, while moulting staging will be referred to as moulting stages.

Five larvae per cylinder were examined to determine the larval instar and moulting stage under $40 x$ and $63 \times$ magnification using a Leica DM LB microscope equipped with an Olympus DP 70 digital camera. The classification system described by Guerao et al. (2010), which is adopted in this paper, comprises both the principal phases (stages $\mathrm{AB}, \mathrm{C}, \mathrm{D}$ and $\mathrm{E}$ ) and subdivisions (substages) of stage $\mathrm{D}\left(\mathrm{D}_{0-1}\right.$ and $\mathrm{D}_{2}$, according to the larval instar). For each moulting stage and larval instar, 40 individuals were used to measure growth in body size and dry weight (DW; $\mathrm{n}=10$ and 30 , respectively); the rest were stored at $-80^{\circ} \mathrm{C}$ for later biochemical analyses (minimum $500 \mathrm{mg}$ of fresh weight of larvae).

Measurements taken from zoeal stages and megalopa were carapace length (CL) and width (CW). For zoeal instars, CL corresponded to the distance measured from between the eyes, at the base of the rostrum, to the posterolateral carapace margin, and CW corresponded to the distance measured from the tip of one lateral spine to the tip of the other lateral spine. For the megalopa, CL was measured from the base of the rostrum (frontal margin) to the posterodorsal margin of the carapace, and CW was measured as the maximum carapace width. For juveniles, CL was measured as the distance between the rostral margin (without rostral spines) and the posterior margin of the carapace (without intestinal spines), and $\mathrm{CW}$ was measured as the maximum carapace width. Measurements were taken using a Nikon SMZ800 stereomicroscope under $40 \times$ and $63 \times$ mag- nification connected to an Olympus DP25 digital camera and an image analysis device (AnalySIS, SIS). Thirty larvae per instar and moulting stage in each batch of larvae ( 6 per replicate, $n=5$ ) were gently rinsed in distilled water and blotted on filter paper for wet weight measurements. After oven-drying for $24 \mathrm{~h}$ at $60^{\circ} \mathrm{C}$, DW was determined on a Sartorius BP211D balance to the nearest $0.001 \mathrm{mg}$. The ash content was measured after $4 \mathrm{~h}$ combustion at $450^{\circ} \mathrm{C}$ in a muffle furnace.

\section{Biochemical analyses}

Larval samples for proximate biochemical analysis were gently rinsed in distilled water, dried on filter paper and kept frozen at $-80^{\circ} \mathrm{C}$ until analysis. Tissue homogenization from larvae reared from the 4 different batches in each instar and moulting stage (13 larval stages $\times 4$ batches) was carried out on ice $\left(4^{\circ} \mathrm{C}\right)$ and attained after 5 min disruption with an Ultra Turrax T-25 (IKA WERKE) and 1 min sonication (Vibracell, Sonics). Three subsamples of each homogenate were used to estimate the proximal composition of the larvae. The methods of Lowry et al. (1951) and Dubois et al. (1956) were used to determine protein and carbohydrate content, respectively. Protein in the samples was previously digested with $\mathrm{NaOH} 1 \mathrm{~N}$ at $60^{\circ} \mathrm{C}$ for $30 \mathrm{~min}$ to allow for better performance of the test. Total lipid content was quantified gravimetrically after extraction following the method of Folch et al. (1957). The individual content $\left(\mu \mathrm{g} l \mathrm{larva}^{-1}\right)$ of each biochemical component was calculated on a DW basis.

\section{Statistical analyses}

Statistical analysis was performed using SigmaStat 3 (Systat Software). Larvae hatched from females captured from the Catalan coast and Corsica did not show any significant difference in any biomass or proximal composition variable considered (Student's $t$-test, $\mathrm{p}>0.05$ ); therefore, all larvae regardless of the origin of the broodstock, were pooled for further analysis, and the number of samples (females) was $\mathrm{n}=4$. Ontogenetic changes in body size, DW and proximal biochemical content (data were log transformed where necessary) were described by means of linear or non-linear regressions $(95 \%$ confidence intervals of the regression coefficients). Differences between stages and instars were tested by one-way ANOVA. Normality and homogeneity of variance 
were tested with Kolmogorov-Smirnov and Levene's tests, respectively. Comparisons between groups after finding significant differences were performed by either Holm-Sidak or Tukey's tests, depending on the results, with an overall significance level of 0.05 . Biometric, biomass and biochemical data are given as means $\pm \mathrm{SD}$.

\section{RESULTS}

\section{Survival and larval stage duration}

Survival remained high until zoea II (ZII) in intermoult stage $(C)(71.79 \pm 2.46 \%)$, and then subsequently decreased to $59.25 \pm 19.53 \%$ and $33.49 \pm$ 19.53 in the ZII and megalopa (M) stages, respectively; only $7.74 \pm 1.94 \%$ of NHL reached the first juvenile instar (C1) (Fig. 1). Survival decreased during ecdysis in all instars, and the differences were not significant from zoea I (ZI) to ZII $(79.93 \pm 4.49 \%$ vs. $78.77 \pm 8.11 \%)$, significant during ecdysis from ZII to M (59.25 $\pm 19.53 \%$ vs. $33.49 \pm 4.27 \%)$ and high from $\mathrm{M}$ to $\mathrm{C}(12.76 \pm 6.18 \%$ vs. $7.74 \pm 1.94 \%)\left(F_{12,39}=\right.$ $58.52, \mathrm{p}<0.001)$. Mortality was also observed in premoult stages in each developmental instar: differences in survival between stages $\mathrm{C}$ and $\mathrm{D}_{2}$ were $92.48 \pm 2.43 \%$ vs. $79.93 \pm 4.49 \%$ for $\mathrm{ZI}, 71.79 \pm$ $2.46 \%$ vs. $59.25 \pm 19.53 \%$ for ZII and $31.82 \pm 13.04 \%$ vs. $12.76 \pm 6.18 \%$ for $\mathrm{M}\left(F_{12,39}=58.52, \mathrm{p}<0.001\right)$.

Moulting from ZI to ZII occurred at $4 \mathrm{~d}$ posthatching (dph) and from ZII to M at 8 dph. The first juvenile crabs (C1) were observed at $14 \mathrm{dph}$ (Fig. 1), but it was not until 17 dph that $97 \%$ of the population in the cylinder became $\mathrm{C} 1$. The experiments were terminated when the first juvenile crabs appeared, settling on the mesh bottom of the culture cylinders.

\section{Growth in size and weight}

Newly hatched zoeae of Maja squinado had a mean CL of $1079 \pm 60 \mu \mathrm{m}$ and a mean CW of $898 \pm 38 \mu \mathrm{m}$ (Table 1). Significant size differences among instars were observed at megalopa and $\mathrm{C} 1 \mathrm{for}$ CL $\left(F_{12,39}=150.486, \mathrm{p}<0.001\right)$ and $\mathrm{CW}$ $\left(F_{12,39}=90.772, \mathrm{p}<0.001\right)$. No differences in size were observed among the different moulting stages within a single developmental instar.

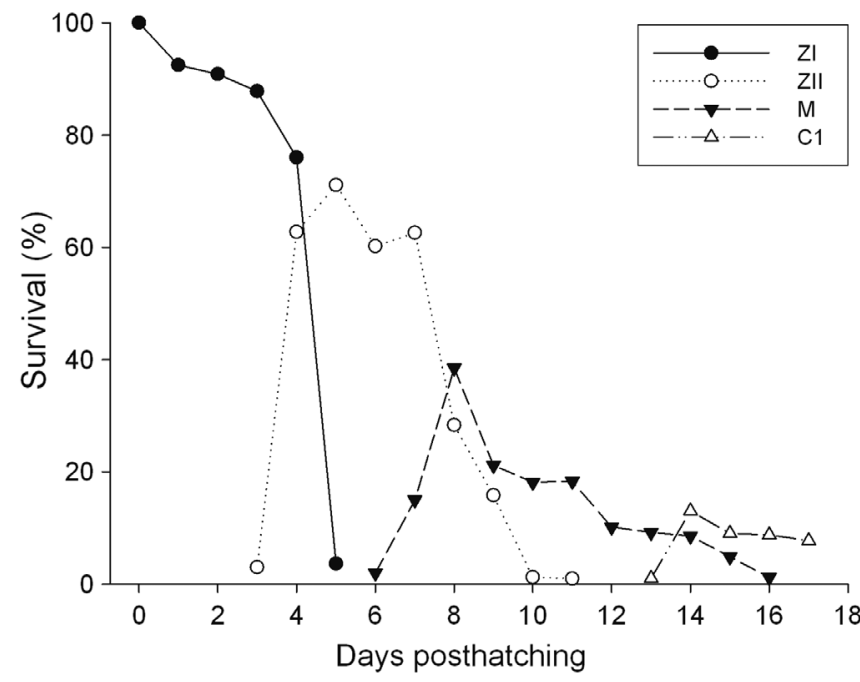

Fig. 1. Maja squinado. Percentage survival and occurrence of successive larval instars. C1: first juvenile crab; M: megalopa; ZI: zoea I; ZII: zoea II

The increase in DW during the course of larval development from hatching through metamorphosis suggested an exponential pattern of growth (Fig. 2.; see equation parameters). From the day of hatching to the C1 stage, the increment in DW was 5.5-fold. Significant differences were observed in DW between the different larval stages in intermoult (C) $(155.27 \pm 3.86 \mu \mathrm{g}$ in $\mathrm{ZI}, 267.11 \pm 15.24 \mu \mathrm{g}$ in $\mathrm{ZII}$ and $329.87 \pm 38.26 \mu \mathrm{g}$ in M). Differences in DW among

Table 1. Maja squinado. Morphometrical characteristics of different larval instars and the first juvenile throughout the moult cycle from 4 different hatching events $(n=4)$ : first juvenile crab (crab 1$)$, megalopa, and zoea I and II. Data are shown as means \pm SD. Different letters (superscripts) in the carapace length (CL) and width (CW) columns denote significant differences among stages $(p<0.05)$

\begin{tabular}{|lccc|}
\hline $\begin{array}{l}\text { Developmental } \\
\text { instar }\end{array}$ & $\begin{array}{c}\text { Moulting stage } \\
\text { or substage }\end{array}$ & CL $(\mu \mathrm{m})$ & CW $(\mu \mathrm{m})$ \\
\hline Zoea I & $\mathrm{AB}$ & $1078.98 \pm 60.17^{\mathrm{e}, \mathrm{d}}$ & $897.55 \pm 38.37^{\mathrm{f}, \mathrm{e}}$ \\
& $\mathrm{C}$ & $1071.75 \pm 82.62^{\mathrm{e}}$ & $831.71 \pm 52.28^{\mathrm{f}}$ \\
& $\mathrm{D}_{0-1}$ & $1075.75 \pm 52.09^{\mathrm{e}, \mathrm{d}}$ & $872.00 \pm 53.14^{\mathrm{f}, \mathrm{e}}$ \\
& $\mathrm{D}_{2}$ & $1083.62 \pm 8.96^{\mathrm{e}, \mathrm{d}}$ & $886.71 \pm 0.54^{\mathrm{f}, \mathrm{e}}$ \\
Zoea II & $\mathrm{AB}$ & $1222.99 \pm 29.81^{\mathrm{c}, \mathrm{d}}$ & $954.28 \pm 33.79^{\mathrm{d}, \mathrm{e}}$ \\
& $\mathrm{C}$ & $1237.89 \pm 18.04^{\mathrm{c}, \mathrm{d}}$ & $1004.17 \pm 20.26^{\mathrm{b}, \mathrm{c}, \mathrm{d}}$ \\
& $\mathrm{D}_{0-1}$ & $1268.18 \pm 33.81^{\mathrm{c}}$ & $1005.94 \pm 24.07^{\mathrm{b}, \mathrm{c}, \mathrm{d}}$ \\
& $\mathrm{D}_{2}$ & $1215.24 \pm 36.26^{\mathrm{c}, \mathrm{d}}$ & $981.88 \pm 11.74^{\mathrm{c}, \mathrm{d}}$ \\
& $\mathrm{AB}$ & $1878.29 \pm 147.19^{\mathrm{b}}$ & $1056.68 \pm 53.07^{\mathrm{b}, \mathrm{c}}$ \\
& $\mathrm{C}$ & $1840.16 \pm 52.15^{\mathrm{b}}$ & $1078.59 \pm 46.51^{\mathrm{b}}$ \\
Crab 1 & $\mathrm{D}_{0-1}$ & $1890.33 \pm 50.33^{\mathrm{b}}$ & $1007.59 \pm 64.96^{\mathrm{b}, \mathrm{c}, \mathrm{d}}$ \\
& $\mathrm{D}_{2}$ & $1862.70 \pm 65.87^{\mathrm{b}}$ & $1039.90 \pm 27.17^{\mathrm{b}, \mathrm{c}, \mathrm{d}}$ \\
& $\mathrm{AB}$ & $2320.55 \pm 122.56^{\mathrm{a}}$ & $1570.00 \pm 6.06^{\mathrm{a}}$ \\
\hline
\end{tabular}




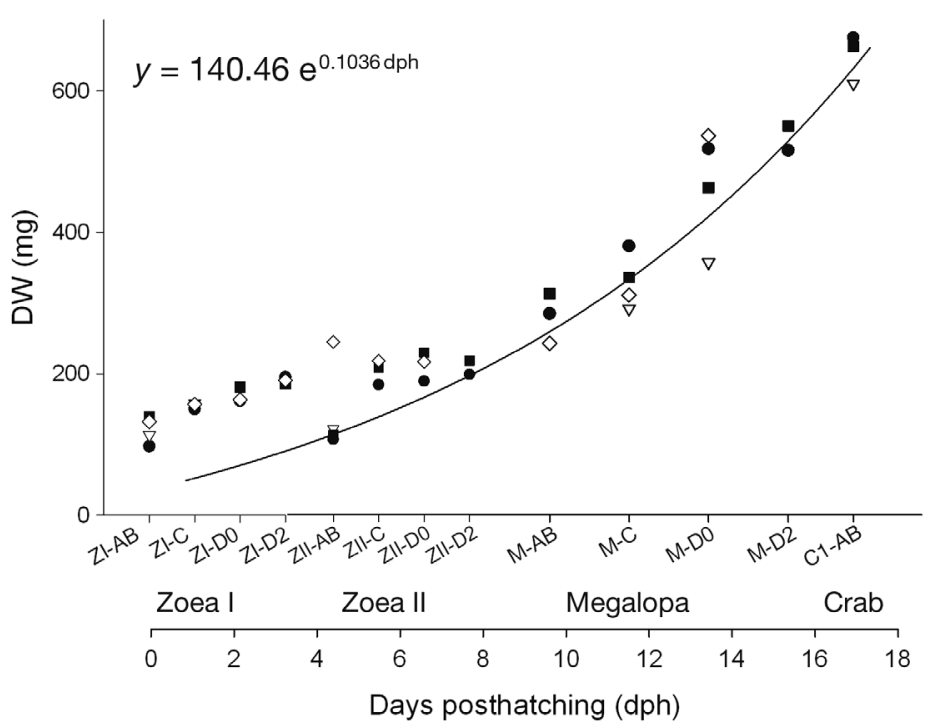

Fig. 2. Maja squinado. Relationship between dry weight (DW) and time of development (days posthatching) among the different larval instars (zoea [Z] I, II, megalopa [M]), moulting stages (AB, C, D0, D2; see 'Materials and methods' for details) and the first juvenile crab (C1). Different symbols represent larvae from different broods

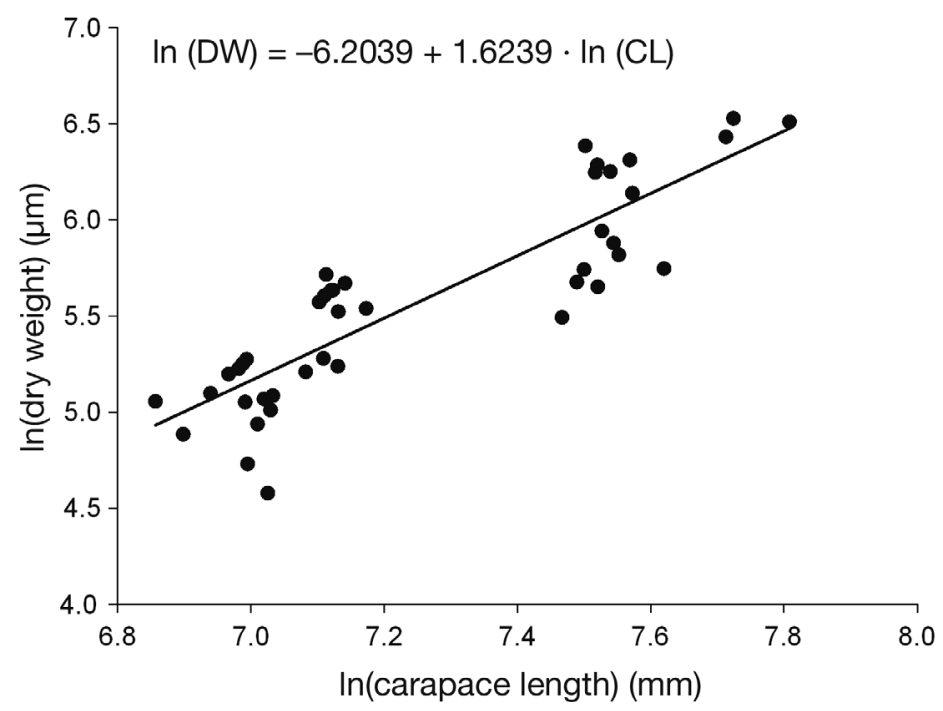

Fig. 3. Maja squinado. Allometric relationship between biomass (dry weight [DW]) and size (carapace length [CL]) in successive larval stages and first juvenile after $\ln -\ln$ transformation of data

moulting stages were only significant in the $\mathrm{M}$ instar, where the postmoult stages $(\mathrm{AB})(280.20 \pm 35.26 \mu \mathrm{g})$ were lighter than the premoult stages (D) (533.05 \pm $\left.24.24 \mathrm{ug}_{i} F_{12,39}=85.350, \mathrm{p}<0.001\right)$. Allometric growth of the larvae was determined by plotting DW and CL after logarithmic transformation of both parameters (Fig. 3). Correlation between biomass and size of the larvae resulted in a coefficient of 1.624 $(r=0.873, \mathrm{p}<0.001, \mathrm{n}=43)$

\section{Ash content and proximate biochemical composition}

Ash content increased from $36.90 \pm 7.64 \mu \mathrm{g}$ in NHL to $244.14 \pm 50.93 \mu \mathrm{g}$ after metamorphosis. The ash content in C1 was significantly different compared with any larval stage. Zoeae increased their ash content during development, but the differences were not significant among them or the newly moulted $\mathrm{M}$ instars. In the $\mathrm{M}$ instars, significant differences were observed between postmoult (51.39 $\pm 18.32 \mu \mathrm{g})$ and premoult $\left(126.66 \pm 39.44 \mu g_{i} F_{12,39}=24.597, \mathrm{p}<\right.$ 0.001). Protein content increased significantly during ontogeny, from $7.90 \pm 0.81 \mu \mathrm{g}$ larvae $^{-1}$ in NHL to $27.83 \pm 0.88 \mu \mathrm{g}$ larvae $^{-1}$ in $\mathrm{C} 1\left(F_{12,39}=7.841, \mathrm{p}<\right.$ $0.001)$; however, higher values of protein content were found in the $\mathrm{M}$ instars in early and late premoult $\left(31.02 \pm 8.99\right.$ and $44.79 \pm 17.14 \mu \mathrm{g}$ larvae $^{-1}$, respectively), although they were not significantly different. Significant differences among moult stages were only observed in the $\mathrm{M}$ instars, increasing from $12.99 \pm 0.39 \mu \mathrm{g}$ larvae $^{-1}$ in late postmoult to $44.79 \pm$ $17.14 \mu \mathrm{g}$ larvae $^{-1}$ in premoult. Lipid levels presented the same significant trend during ontogenic development $\left(4.23 \pm 0.47 \mu \mathrm{g}\right.$ larvae $^{-1}$ in NHL to $17.36 \pm$ $5.87 \mu$ larvae $^{-1}$ in $\mathrm{C} 1$ ) and among moulting stages in $\mathrm{M}\left(10.45 \pm 1.13 \mu \mathrm{g}\right.$ larvae $^{-1}$ in late postmoult to $34.78 \pm 7.36 \mu \mathrm{g}$ larvae $^{-1}$ in premoult; $F_{12,39}=25.250$, $\mathrm{p}<0.001)$. Carbohydrate levels were very low, and although they increased during development, the differences were not significant $(0.42 \pm 0.15 \mu \mathrm{g}$ lar$\mathrm{vae}^{-1}$ in NHL to $0.96 \pm 0.45 \mu \mathrm{g}$ larvae ${ }^{-1}$ in C1). Significant differences in carbohydrate content were observed among moulting stages in $M(0.77 \pm 0.18 \mu \mathrm{g}$ larvae $^{-1}$ in late postmoult to $2.33 \pm 1.12 \mu$ larvae $^{-1}$ in premoult; $F_{12,39}=4.725, \mathrm{p}<0.001$ ).

When the results of ash and proximal content were expressed as a percentage of DW (Fig. 4), significant differences were only observed for ash and lipid values. In the first juvenile stage, ash content represented the major compound, while protein showed the highest levels in all larval developmental instars and moulting stages. Lipid content was the lowest in C1 compared with all other larval instars $\left(F_{12,39}=\right.$ 6.666, $\mathrm{p}<0.001)$.

\section{DISCUSSION}

The present study describes patterns of larval growth in Maja squinado reared under controlled laboratory conditions, allowing predictions of growth in size, biomass and biochemical composition of suc- 


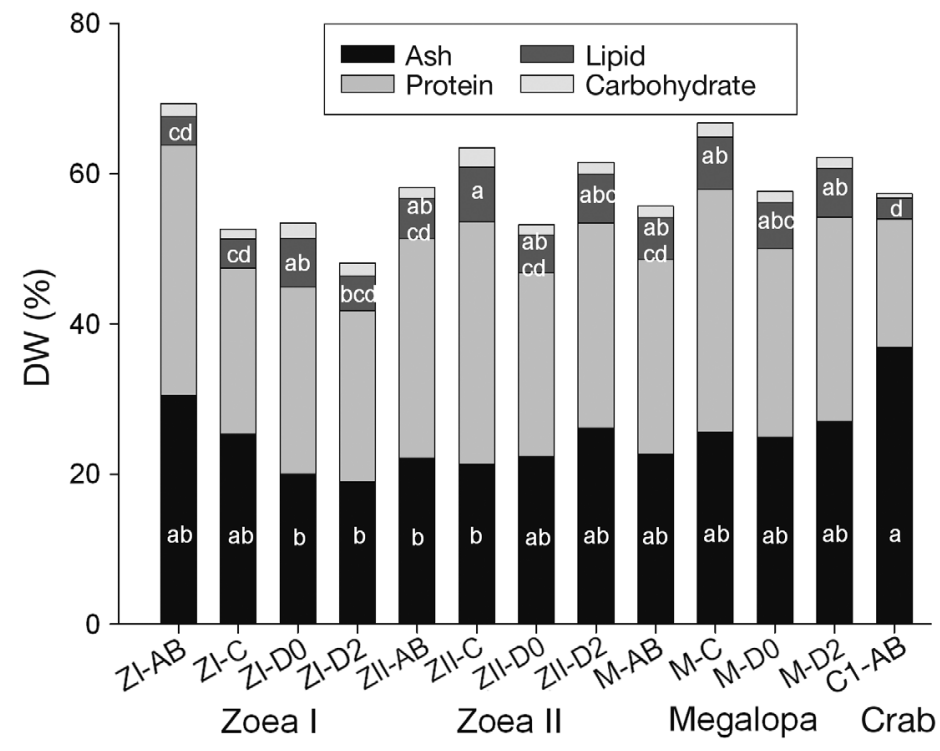

Fig. 4. Maja squinado. Ash content and proximal composition as percentage of dry weight (DW) of the different larval instars and moulting stages and the first juvenile. Developmental instars: $\mathrm{C} 1$, first juvenile crab; $\mathrm{M}$, megalopa; ZI: zoea I; ZII: zoea II. Moulting stages: AB, C, D0, D2 (see 'Materials and methods' for details). Different letters in the ash and lipid content bars denote significant differences between stages $(p<0.05)$

cessive developmental instars and moulting stages. These results can be applied (1) to improve hatchery techniques for the production of juveniles for restocking and (2) to assess the quality of environmental conditions for larval growth (Anger 2001).

Complete larval development of Maja squinado from hatching to the $\mathrm{C} 1$ stage lasted 15 to $17 \mathrm{~d}$ at $18^{\circ} \mathrm{C}$ in this study, which is similar to what was observed by Durán et al. (2012) using a higher rearing temperature $\left(20^{\circ} \mathrm{C}\right)$. The duration of larval instars was also very similar between both studies. In the related species $M$. brachydactyla, increasing the rearing temperature from 15 to $18^{\circ} \mathrm{C}$ shortened the time to metamorphosis by $5 \mathrm{~d}$. Longer periods of development at lower temperature were observed for premoult stages (stage D), being $1 \mathrm{~d}$ longer in each zoea instar and $3 \mathrm{~d}$ longer for the megalopal instar (Guerao et al. 2010). At $18^{\circ} \mathrm{C}$, the duration of moulting stages was similar between $M$. squinado and $M$. brachydactyla. Slight variations in the duration of larval instars in $M$. brachydatyla reared between 15 and $22^{\circ} \mathrm{C}$ were also observed in previous studies (Schlegel 1911, Urcera et al. 1993, Iglesias et al. 2002, Andres et al. 2007, 2008, Palma et al. 2008), suggesting that other factors such as feeding, prey and larval density, water quality and rearing systems might be responsible for such a difference.
Survival was high in zoeal Maja squinado instars and decreased sharply at the $\mathrm{M}$ instar, with only $7 \%$ of the NHL reaching the C1 stage (Durán et al. 2012, present study), which is close to the survival rate reported by other authors in studies of $M$. brachydactyla (13\%, Andrés et al. 2007; 8-13\%, Iglesias et al. 2002), but lower than that achieved by Urcera et al. (1993) (46\%). In the present study, considering the moulting stages in each developmental instar, the highest mortality was found to occur in the early premoult stages. Anger (1987) described the critical points in larval development in 9 decapod species belonging to 8 families and 4 higher taxa (Caridea, Macrura, Anomura and Brachyura) using different morphological and hormonal conditions. Two of the thresholds described by the author as ' $\mathrm{D}_{0}$ threshold' and 'exuviation threshold' agree with the periods of maximal mortality observed in the present study.

An increase in size only occurred after moulting to the next stage, whereas growth in weight increased continuously during moulting stages and developmental instars, as expected. Maja squinado larvae increased in size 2.2-fold in terms of CL and 1.8-fold in terms of CW from hatching to metamorphosis in the present study and in that by Durán et al. (2012), while M. brachydatcyla larvae increased 3.6- and 3.3-fold in terms of CL and CW, respectively (Andrés et al. 2008). Schlegel (1911) measured ZI of M. brachydactyla captured in the Northern Sea (Germany), obtaining values of $1100 \mu \mathrm{m}$ for CL and $800 \mu \mathrm{m}$ for CW, while Andrés et al. (2008) found that newly hatched zoeae from the Galician coast (Spain) had $\mathrm{CL}$ of $570 \mu \mathrm{m}$ and CW of $460 \mu \mathrm{m}$. As reported in other crustacean species, it remains uncertain whether these differences in biomass occurred due to a mere variability among cohorts produced by different hatching events (Anger et al. 1989), or whether they represent differences between conspecific populations (Laughlin \& French 1989, Rotllant et al. 2004).

As in many other Decapoda, the pattern of larval and early postlarval growth in biomass may be described as an exponential relationship of the number of successive instars. Biomass gain per larva from NHL to metamorphosis ( $\mathrm{M}$ in late premoult) ranges from 42 to $5388 \%$ depending on the decapod species studied (Anger \& Harms 1990). In the present study, Maja squinado showed a relatively low biomass gain of $343 \%$. If the results published by Durán et al. (2012) are compared with those of the present experiment, biomass gain would be underestimated since Durán et al.'s (2012) results corresponded to a postmoult megalopa. Both studies confirmed that $M$. squinado growth in biomass follows an exponential trend line 
similar to that previously described for M. brachydactyla (Andrés et al. 2008). The gain in weight calculated from the data presented by Andrés et al. (2008) was slightly lower $(314 \%)$ than that obtained for $M$. squinado in the present study; however. megalopa measurements were taken at the intermoult stage. Biomass gain in another spider crab, Hyas araneus, was 3-fold higher compared with our measurements of Maja spp. (Anger \& Harms 1990); however, both species belong to different families and genetic differences might explain their differences in growth. In our study, a continuous weight increase was observed from hatching to metamorphosis into $\mathrm{C} 1$. In $H$. araneus, weight also increased progressively during all moulting stages in zoea instars, but $M$ growth followed a parabolic pattern (Anger et al. 1989). $\mathrm{M}$ instar duration is 3-fold faster between Maja spp. (Rotllant et al. 2012, present study) and H. araneus (Anger et al. 1989); therefore, the lack of differences during moulting stages of $\mathrm{M}$ in Maja spp. could be explained by the shorter duration of this instar. Crustacean larvae (Anger \& Harms 1990) and adults (Vernet \& Charmantier-Daurès 1994) do not feed during late premoult and early postmoult stages; therefore, the decrease in weight observed in $H$. araneus might be a consequence of a low larval feeding rate and a high energy demand for the moulting processes.

Ash content increased gradually from 37 to $127 \mu \mathrm{g}$ in Maja squinado from NHL to metamorphosis, and increased abruptly when moulting to C1 (244 $\mu \mathrm{g})$. No significant differences in ash content were found among zoea stages, but premoult M presented significantly higher levels than zoeae and significantly lower levels than newly moulted C1. Increases in inorganic matter during the premoult $M$ stages may indicate that the accumulation of minerals and highenergy substances for the calcification of the new exoskeleton has already started. A decrease in ash content between postmoult ZII and premoult M was also observed, as previously reported in $M$. brachydactyla by Urcera et al. (1993). Nevertheless, values from Urcera et al. (1993) were much lower than those observed in the present study. If the results are expressed in terms of percentage DW of the megalopa, both species presented similar values in ash content (Urcera et al. 1993, Andres et al. 2008, present study). Reported values for the first juvenile crab showed a significantly higher ash content, being $37 \%$ for $M$. squinado (present study) and $47 \%$ for $M$. brachydactyla (Andres et al. 2008). Both studies were conducted using the same rearing system and conditions, so the observed differences suggest an adaptation to their different geographic distributions.
Our results show that protein, lipid and carbohydrate contents of Maja squinado increased gradually until moulting to $\mathrm{M}_{\text {; }}$ in $\mathrm{M}$ moulting stages, this increment is sharp and then values decreased when moulting to C1. In M. brachydactyla, Andrés et al. (2008) also observed an increase in the protein, lipid and carbohydrate composition of the larvae and a decrease after metamorphosis. Lipid content was very similar between both species, while protein and carbohydrate content was between 3- and 20-fold higher in $M$. squinado than in $M$. brachydactyla. Andrés et al. (2008) and Anger \& Harms (1990) measured similar levels of protein content for $M$. brachydactyla larvae. These results suggest that differences in the protein and carbohydrate composition of larval $M$. squinado and $M$. brachydactyla are either due to genotypic differences or are phenotypically induced by the surrounding environment. Protein comprises the major component of larvae. Since variations among stages in percentage of protein were not significantly different (differences were only detected in terms of lipid content), we might conclude that lipids are the main source of energy used by $M$. squinado larvae during development. Preferential utilization of lipid reserves is a widespread pattern in crustacean species, although some species may use different biochemical substrates for energy production during starvation (for a review, see Sánchez-Paz et al. 2006). Thus, in premoult stages, spider crab larvae have a higher concentration of proteins compared with lipids, as has been reported in other crustacean decapod larvae (Anger 1998). These physiologically different phases of growth have been interpreted by Anger (1998) as an initial period of rapid lipid storage in the larval hepatopancreas, followed by the production of proteinrich integument and muscle tissues. A correlation between proximal and elemental composition has been reported by Gnaiger \& Bitterlich (1984). If we assume the same correlation, results from this study in $M$. squinado showed that zoea instars presented a decrease in protein and lipid content in premoult stages, as previously reported by Rotllant et al. (2012) in terms of nitrogen and carbon in $M$. brachydactyla. Nevertheless, in megalopa, both Rotllant et al. (2012) and the present study showed an increase in proximal or elemental composition during moulting stages. In Hyas areneus, Anger et al. (1989) also observed a decrease in lipid and protein content during the second part of the moult cycle in zoeae instars and megalopa.

The present study shows that differences in biomass and biochemical composition of the early developmental stages of Maja squinado and M. brachydactyla exist, even though their development and morphology 
are very similar. These differences might be influenced by a genetic component or could be a response to different environmental conditions. It is important to analyse the biochemical composition of the larvae of different species since it reflects the differences in the nutritional requirements for each species, particularly in the case of $M$. squinado, where the aim is to produce juveniles to re-stock the population in the Mediterranean Sea.

Acknowledgements. Bench fees were provided by Junta Asesora de Cultivos Marinos (JACUMAR) (REPES project) to G.R. Financial support was provided by the Ministry of Science and Research to G.G. (post-doctoral fellowship; Instituto Nacional de Investigación y Tecnología Agraria y Alimentaria). The authors thank Glòria Macià for support as a hatchery technician at Institut de Recerca i Tecnologia Agroalimentàries (IRTA), Sant Carles de la Ràpita.

\section{LITERATURE CITED}

Abad R (2003) Reserva marina y pesca en la isla de Alborán (España) In: Moreno D, Frías A (eds) Proc Actas de las I Jornadas sobre Reservas Marinas y I Reunión de la Red Iberoamericana de Reservas Marinas (RIRM). Ministerio de Agricultura, Pesca y Alimentación. Secretaría General Técnica, Madrid

> Andrés M, Estévez A, Rotllant G (2007) Growth, survival and biochemical composition of spider crab Maja brachydactyla (Balss, 1922) (Decapoda: Majidae) larvae reared under different stocking densities, prey: larva ratios and diets. Aquaculture 273:494-502

> Andrés M, Estévez A, Anger K, Rotllant G (2008) Developmental patterns of larval growth in the edible spider crab, Maja brachydactyla (Decapoda: Majidae). J Exp Mar Biol Ecol 357:35-40

Andrés M, Estévez A, Hontoria F, Rotllant G (2010) Differential utilization of biochemical components during larval development of the spider crab Maja brachydactyla (Decapoda: Majidae). Mar Biol 157:2329-2340

Anger K (1987) The $\mathrm{D}_{0}$ threshold: a critical point in the larval development of decapod crustaceans. J Exp Mar Biol Ecol 108:15-30

- Anger K (1998) Patterns of growth and chemical composition in decapod crustacean larvae. Invertebr Reprod Dev 33:159-176

Anger K (2001) The biology of decapod crustacean larvae. A. A. Balkema Publishers, Lisse

Anger K, Harms J (1990) Elemental (CHN) and proximate biochemical composition of decapod crustacean larvae. Comp Biochem Physiol 97B:69-80

Anger K, Harms J, Püschel C, Seeger B (1989) Physiologic and biochemical changes during the larval development of a brachyuran crab reared under constant conditions in the laboratory. Helgol Meeresunters 43:225-244

Anonymous (1998) Autorización de tratados y convenios internacionales. Protocolo sobre las zonas especialmente protegidas y la diversidad biológica en el Mediterráneo. Boletín Ofical de las Cortes Generales, Sección Cortes Generales Serie A Num 237. Available at www.congreso. es/public_oficiales/L6/CORT/BOCG/A/CG_A237.pdf
Anonymous (1999) Décret no 99-615 du 7 juillet 1999 portant publication des amendements aux annexes I, II III et IV de la convention relative à la conservation de la vie sauvage et du milieu naturel de l'Europe (ensemble quatre annexes) ouverte à la signature à Berne le 19 septembre 1979, adoptés à Strasbourg le 5 décembre 1997. J Off Repub Fr 164:10741-10757. Available at www. legifrance.gouv.fr/affichTexte.do? cidTexte=JORFTEXT0 00000577218\&dateTexte $=\&$ categorieLien $=$ id

Bell JD, Leber KM, Blankenship HL, Loneragan NR, Masuda R (2008) A new era for restocking, stock enhancement and sea ranching of coastal fisheries resources. Rev Fish Sci 16:1-9

> Daly B, Swingle JS, Eckert GL (2009) Effects of diet, stocking density, and substrate on survival and growth of hatchery-cultured red king crab (Paralithodes camtschaticus) juveniles in Alaska, USA. Aquaculture 293: 68-73

> Daly B, Swingle JS, Eckert GL (2012) Increasing hatchery production of juvenile red king crabs (Paralithodes camtschaticus) through size grading. Aquaculture 364-365: 206-211

> Daly B, Swingle JS, Eckert GL (2013) Dietary astaxanthin supplementation for hatchery-cultured red king crab, Paralithodes camtschaticus, juveniles. Aquacult Nutr 19: 312-320

Dubois M, Gilles KA, Hamilton JK, Rebers PA, Smith F (1956) Colorimetric method for determination of sugars and related substances. Anal Chem 28:350-356

d'Udekem d'Acoz C (1999) Inventaire et distribution des crustacés décapodes de l'Atlantique nord-oriental, de la Méditerranée et des eaux continentales adjacentes au nord de $25^{\circ} \mathrm{N}$. Muséum National d'Histoire Naturelle, Service du Patrimoine Naturel, Paris

> Durán J, Pastor E, Grau A, Valencia JM (2012) First results of embryonic development, spawning and larval rearing of the Mediterranean spider crab Maja squinado (Herbst) under laboratory conditions, a candidate species for a restocking program. Aquacult Res 43:1777-1786

> Durrieu de Madron X, Guieu C, Sempéré R, Conan P and others (2011) Marine ecosystems' responses to climatic and anthropogenic forcings in the Mediterranean. Prog Oceanogr 91:97-166

Folch J, Lees M, Stanley GHS (1957) A simple method for the isolation and purification of total lipids from animal tissues. J Biol Chem 226:497-509

> Gnaiger E, Bitterlich G (1984) Proximate biochemical composition and caloric content calculated from elemental CHN analysis: a stoichiometric concept. Oecologia 62: 289-298

Guerao G, Rotllant G (2010) Development and growth of the early juveniles of the spider crab Maja squinado (Brachyura: Majoidea) in an individual culture system. Aquaculture 307:105-110

> Guerao G, Pastor E, Martin J, Andres M and others (2008) The larval development of Maja squinado and M. brachydactyla (Decapoda, Brachyura, Majidae) described from plankton collected and laboratory-reared material. J Nat Hist 42:2257-2276

- Guerao G, Rotllant G, Anger K (2010) Characterization of larval moulting cycles in Maja brachydactyla (Brachyura, Majidae) reared in the laboratory. Aquaculture 302: 106-111

Guerao G, Andree KB, Froglia C, Simeo CG, Rotllant G (2011) Identification of European species of Maja (Decapoda: 
Brachyura: Majidae): RFLP analyses of COI mtDNA and morphological considerations. Sci Mar 75:129-134

Iglesias J, Sánchez FJ, Moxica C, Fuentes L, Otero JJ, Pérez JL (2002) Datos preliminares sobre el cultivo de larvas y juveniles de centolla Maja squinado Herbst, 1788 en el Centro Oceanográfico de Vigo del Instituto Español de Oceanografía. Bol Inst Esp Oceanogr 18:25-30

> Laughlin RB Jr, French W (1989) Differences in responses to factorial combinations of temperature and salinity by zoeae from two geographically isolated populations of the mud crab Rhithropanopeus harrisii. Mar Biol 102: 387-395

- Lebata M, Le Vay L, Walton ME, Binas JB, Quinitio ET, Rodriguez EM, Primavera JH (2009) Evaluation of hatchery-based enhancement of the mud crab, Scylla spp., fisheries in mangroves: comparison of species and release strategies. Mar Freshw Res 60:58-69

> Liu ZM, Wang GZ, Ye HH, Li SJ, Tao Y, Lin QW, Mohammed EH (2011) Tag performance and physiological responses of juvenile mud crabs Scylla paramamosain tagged with visible implant elastomer. Fish Res 110: 183-188

> Lorenzen K, Beveridge MCM, Mangel M (2012) Cultured fish: integrative biology and management of domestication and interactions with wild fish. Biol Rev Camb Philos Soc 87:639-660

Lowry OH, Rosenberg NJ, Farr AL, Randall RJ (1951) Protein measurement with the Folin phenol reagent. J Biol Chem 193:265-275

Neumann V (1998) A review of the Maja squinado (Crustacea: Decapoda: Brachyura) species-complex with a key to the eastern Atlantic and Mediterranean species of the genus. J Nat Hist 32:1667-1684

Okamoto K (2004) Juvenile release and market size recapture of the swimming crab Portunus trituberculatus (Miers) marked with coded wire tags. In: Leber KM, Kitada S, Blankenship HL, Svasand T (eds) Stock enhancement and sea ranching: developments, pitfalls and opportunities. Blackwell Publishing, Oxford

Palma J, Correia M, Andrade JP (2008) Usefulness of flat bottom tanks on the settlement of spider crab (Maja squinado, Herbst) larvae. Aquacult Res 39:1005-1008

Pastor E, Durán J, Caimari MA (2011) Experiences in mass production of mediterranean spider crab Maja squinado juveniles for restocking studies. In: Proc Aquaculture Europe 2011, 18-21 October 2011 Rhodes. European Aquaculture Society, Oostende, p 843-844

Rotllant G, Anger K, Durfort M, Sarda F (2004) Elemental and biochemical composition of Nephrops norvegicus (Linnaeus 1758) larvae from the Mediterranean and Irish Seas. Helgol Mar Res 58:206-210

Rotllant G, Alaminos J, Cerezo J, Fernández-Palacios E,
Pastor E (2010a) Cría de centolla (Maja sp.). In: Informe final Junta de cultivos marinos Planes nacionales de cultivos marinos. JACUMAR, Madrid, Spain

Rotllant G, Moyano FJ, Andres M, Estevez A, Diaz M, Gisbert $\mathrm{E}(2010 \mathrm{~b})$ Effect of delayed first feeding on larval performance of the spider crab Maja brachydactyla assessed by digestive enzyme activities and biometric parameters. Mar Biol 157:2215-2227

Rotllant G, Guerao G, Sastre M, Anger K (2012) Developmental and moult-cycle related biochemical changes in larval spider crab, Maja brachydactyla (Brachyura, Majidae). Sci Mar 76:483-488

Sánchez-Paz A, García-Carreno F, Muhlia-Almazán A, Peregrino-Uriarte AB, Hernández-López J, Yepiz-Plascencia G (2006) Usage of energy reserves in crustaceans during starvation: status and future directions. Insect Biochem Mol Biol 36:241-249

Schlegel MC (1911) Sur le développement de Maia squinado Latr. C R Acad Sci Paris 153:480-482

> Sotelo G, Moran P, Posada D (2008) Genetic identification of the northeastern Atlantic spiny spider crab as Maja brachydactyla Balss, 1922. J Crustac Biol 28:76-81

> Sotelo G, Moran P, Posada D (2009) Molecular phylogeny and biogeographic history of the European Maja spider crabs (Decapoda, Majidae). Mol Phylogenet Evol 53: 314-319

> Swingle JS, Daly B, Hetrick J (2013) Temperature effects on larval survival, larval period, and health of hatcheryreared red king crab, Paralithodes camtschaticus. Aquaculture 384-387:13-18

UNEP (United Nations Environment Programme) (1996) Acta final de la reunión de plenipotenciarios sobre los anexos del protocolo referente a las zonas especialmente protegidas y la diversidad biológica en el Mediterráneo. UNEP(OCA)/MED IG 10/4. UNEP, Monaco

Urcera M, Arnaiz R, Rua N, Coo A (1993) Cultivo de la centolla Maja squinado: influencia de la dieta en el desarrollo larvario. Actas IV Congreso Nacional de Acuicultura, Centro de Investigacións Mariñas, Vilanova de Arousa. Sociedad Española de Acuicultura, p 269-274

Ut VN, Le Vay L, Nghia TT, Walton M (2007) Comparative performance of hatchery-reared and wild Scylla paramamosain (Estampador, 1949) in pond culture. Aquacult Res 38:1593-1599

Vernet G, Charmantier-Daurès M (1994) Mue, autotomie et régéneration. In: Grassé PP (ed) Traité de zoologie anatomie, systématique, biologie. Book VII. Crustacés. Masson, Paris

Zohar Y, Hines A, Zmora O, Johnson E and others (2008) The Chesapeake Bay blue crab (Callinectes sapidus): a multidisciplinary approach to responsible stock replenishment. Rev Fish Sci 16:24-34

Submitted: April 3, 2013; Accepted: August 15, 2013

Proofs received from author(s): November 17, 2013
Editorial responsibility: Bernard Sainte-Marie, Mont-Joli, Quebec, Canada 